http://dx.doi.org/10.11646/phytotaxa.161.4.5

\title{
Additions to the Ricciaceae flora of Rio Grande do Sul, including two remarkable records for the Brazilian liverwort flora
}

\author{
DANIEL MARTINS AYUB ${ }^{1}$, DENISE PINHEIRO DA COSTA ${ }^{2} \&$ RINALDO PIRES DOS SANTOS ${ }^{3}$ \\ ${ }^{I}$ Instituto Federal de Educação, Ciência e Tecnologia do Rio Grande do Sul, Av. Osvaldo Aranha 540, Juventude da Enologia, 95700- \\ 000, Bento Gonçalves, RS, Brazil; e-mail: daniayub@bento.ifrs.edu.br \\ ${ }^{2}$ Instituto de Pesquisas Jardim Botânico do Rio de Janeiro, Rua Pacheco Leão 915, 22460-030, Rio de Janeiro, RJ, Brazil; \\ e-mail:dcosta@jbrj.gov.br \\ ${ }^{3}$ Departamento de Botânica, Instituto de Biociências, Universidade Federal do Rio Grande do Sul, Av. Bento Gonçalves 9500, 91501 - \\ 970, Porto Alegre, RS, Brazil; e-mail: rinaldo.santos@ufrgs.br
}

\begin{abstract}
The first record of Riccia boliviensis and $R$. iodocheila for Brazil and the first record of R. squamata and R. subplana for the liverwort flora of the state of Rio Grande do Sul are reported. The species were found during a floristic revision of the family Ricciaceae in the state. Taxonomic notes, photographs, habitat and geographic distribution are provided for each species.
\end{abstract}

Key words: liverworts, Ricciaceae, new records, southern Brazil

\section{Introduction}

The genus Riccia Linnaeus (1753:1138), the largest genus of the Marchantiales, comprises about 150 species worldwide (from the Arctic to the Antarctic). Brazil harbors the highest species diversity with 32 species in four subgenera (60\% of Neotropical species of Riccia). Most species occur in areas with dry seasons (Bischler-Causse et al. 2005) and are terrestrial, growing on soil, usually as pioneers of bare soil and often in areas that are occasionally flooded (Jovet-Ast 1991, 1993; Vianna 1985; Gradstein \& Costa 2003; Bischler-Causse et al. 2005).

The first extensive revision of the genus Riccia for the Neotropics was published by Jovet-Ast $(1991,1993)$. Fifty-two taxa were treated including genus and species descriptions, geographical distributions, and illustrations. In Brazil, Vianna (1985) treated the genus Riccia in the revision of the Marchantiales for the state of Rio Grande do Sul, including 14 species. Gradstein \& Costa (2003) reported the occurrence of 29 species of Riccia for Brazil, 18 of these for Rio Grande do Sul. The most recent revision of Riccia was contributed by Jovet-Ast in Bischler-Causse et al. (2005) Flora Neotropica Monograph for Marchantiidae, that reported the occurrence of 32 species of Riccia for Brazil, 19 of these for Rio Grande do Sul. Species of this genus are delimited morphologically by characters of the thallus (cross section), scales (color and arrangement), and spores (shape, wall ornamentation, and size). Here we report four new records of Riccia for Rio Grande do Sul (Riccia boliviensis Jovet-Ast (1991:242), R. iodocheila M. Howe (1934:200), R. squamata Nees in Martius (1833:302) and R. subplana Stephani (1902:275)); the records of $R$. boliviensis and $R$. iodocheila are also the first from Brazil.

\section{Taxonomic treatment}

Key to the Riccia species from Rio Grande do Sul state (based on Jovet-Ast in Bischler-Causse et al. 2005 and Gradstein \& Costa 2003)

1. Thallus only $2-3$ cell layers thick throughout. Thallus segments widened to the tips. Spores spherical, $40-60 \mu \mathrm{m}$ diam., wingless, spiny, with rounded or truncate spines R. membranacea (subgen. Leptoriccia) 
Riccia squamata is typical of the Caatinga in Brazil (Paraíba, Pernambuco, Bahia, Piauí, and Minas Gerais states) a unique biome in Brazil and very distinct from those found in Rio Grande do Sul, the Campos Sulinos (Southern Brazilian Campos) and the Atlantic Forest. We expected to find this species in the Rio Grande do Sul state, because it is also found in northern Argentina and in the open areas of Campos Sulinos where the conditions of intense luminosity are similar. The discontinuous distribution in Brazil may partly be explained by the few inventories of Ricciaceae in the country.

The widespread distribution of $R$. iodocheila, from the southern USA to Argentina, suggested that it could occur in southern Brazil, which was confirmed in our study. Other species that are expected to occur in Rio Grande do Sul are $R$. crystallina Linnaeus (1753:1138), R. frostii Austin (1875:17), $R$. mauryana Stephani (1898:19), $R$. sorocarpa Bischoff (1835:1053), and $R$. weinionis Stephani (1898:18), which occur elsewhere in Brazil and/or in neighboring Argentina and Paraguay.

These results suggest the need for additional fieldwork to have a better understanding of the distribution and ecology of the species of Riccia in southern Brazil.

\section{Acknowledgements}

We thank the Instituto de Pesquisas Jardim Botânico do Rio de Janeiro, Laboratório de Anatomia Vegetal (LAVeg) of Universidade Federal do Rio Grande do Sul (UFRGS), and the Instituto Federal de Educação, Ciência e Tecnologia do Rio Grande do Sul campus Bento Gonçalves. Financial support for this work came from LAVeg and Programa de Pós Graduação em Botânica of UFRGS.

\section{References}

Austin, C.F. (1875) New Hepaticae. Bulletin of the Torrey Botanical Club 6: 1-379. http://dx.doi.org/10.2307/2475861

Bischler-Causse, H., Gradstein, S.R., Jovet-Ast, S. Long, D.G. \& Salazar Allen, N. (2005) Marchantiidae. Flora Neotropica 97:1-262.

Bischoff, G.W. (1835) Bemerkungen Uber die Lebermoose vorzüglich aus den Gruppen der Marchantienn und Riccien. Nova Acta Physico-Medica Academiae Caesareae Leopoldino-Carolinae Naturae Curiosorum 17(2): 909-1088.

Gradstein, S.R. \& Costa, D.P. (2003) The Hepaticae and Anthocerotae of Brazil. Memoirs of the New York Botanical Garden 87: $1-318$.

Hässel de Menéndez, G. (1963) Estudio de las Anthocerotales y Marchantiales de la Argentina. Opera Lilloana 7: 1-297.

Howe, M. (1934) The Hepaticae (chiefly Riccia and Anthocerotaceae) of the Galapagos Islands and the coast and islands of Central America and Mexico. Proceedings of California Academy of Sciences Series 4 21: 199-210.

Jovet-Ast, S. (1991) Riccia (Hépatiques, Marchantiales) d'Amérique Latine. Taxons du Sous-Genre Riccia. Cryptogamie, Bryologie Lichénologie 12(3): 189-370.

Jovet-Ast, S. (1993) Riccia (Hépatiques, Marchantiales) d'Amérique Latine. Taxon des sous-genres Thallocarpus, Leptoriccia, Ricciella. Cryptogamie, Bryologie Lichénologie 14(3): 219-301.

Jovet-Ast, S. (2005) Riccia In: Bischler-Causse, H., Gradstein, S.R., Jovet-Ast, S. Long, D.G. \& Salazar Allen, N. (2005) Marchantiidae. Flora Neotropica 97: 25-123.

Linnaeus, C. (1753) Species plantarum 2: 561-1200. http://dx.doi.org/10.5962/bhl.title.669

Leite, P.F. \& Klein, R.M. (1990) Geografia do Brasil. Região Sul. Rio de Janeiro, IBGE.

Martius, C.F.P. (1833) Flora Brasilinesis, Pars Prior. (Stuttgart \& Tübingen) 293-390.

Schiffner, V. \& Arnell, S.W. (1964) Ergebnisse der Botanischen Expedition der kaiserlichen Akademie der Wissenschaften nach Südbrasilien. II. Hepaticae. Österreichische Akademie der Wissenschaften. Mathematisch-Naturwissenschaftliche Klasse. Denkschriften 111:1-156.

Stephani, F. (1897) Die Lebermoose der ersten Regnell'schen Expedition nach Südamerika. Bihang til Kongliga Svenska Vetenskaps-Akademiens Handlingar 23 (III, 2): 1-36.

Stephani, F. (1898-1900) Species hepaticarum: eine Darstellung ihrer Morphologie und Beschreibung ihrer Gattungen wie aller bekannten Arten in Monographien unter Berücksichtigung ihrer gegenseitigen Verwandtschaft und geographischen Verbreitung. Georg, Geneve \& Bale. 1-438.

http://dx.doi.org/10.5962/bhl.title.45014

Stephani, F. (1902) Urban. Symbolae Antillanae 3:275-279.

Vianna, E.C. (1985) Flora Ilustrada do Rio Grande do Sul, 15, Marchantiales. Bol. Boletim do Instituto de Biociências (Porto Alegre) 38: 1-213. 